\title{
mGluR5 Has a Critical Role in Inhibitory Learning
}

\author{
Jian Xu, ${ }^{1}$ Yongling Zhu, ${ }^{1}$ Anis Contractor, ${ }^{2}$ and Stephen F. Heinemann ${ }^{1}$ \\ ${ }^{1}$ The Salk Institute for Biological Studies, Molecular Neurobiology Laboratory, La Jolla, California 92037, and ${ }^{2}$ Department of Physiology, Northwestern \\ University Feinberg School of Medicine, Chicago, Illinois 60611
}

The mechanisms that contribute to the extinction of previously acquired memories are not well understood. These processes, often referred to as inhibitory learning, are thought to be parallel learning mechanisms that require a reacquisition of new information and suppression of previously acquired experiences in order to adapt to novel situations. Using newly generated metabotropic glutamate receptor 5 (mGluR5) knock-out mice, we investigated the role of mGluR5 in the acquisition and reversal of an associative conditioned task and a spatial reference task. We found that acquisition of fear conditioning is partially impaired in mice lacking mGluR5. More markedly, we found that extinction of both contextual and auditory fear was completely abolished in mGluR5 knock-out mice. In the Morris Water Maze test (MWM), mGluR5 knock-out mice exhibited mild deficits in the rate of acquisition of the regular water maze task, but again had significant deficits in the reversal task, despite overall spatial memory being intact. Together, these results demonstrate that mGluR5 is critical to the function of neural circuits that are required for inhibitory learning mechanisms, and suggest that targeting metabotropic receptors may be useful in treating psychiatric disorders in which aversive memories are inappropriately retained.

\section{Introduction}

Metabotropic glutamate receptors (mGluRs) modulate neural activity via their linkage to various intracellular cascades (Nakanishi, 1992). The eight individual mammalian mGluRs can be subdivided into three groups based on their sequence homologies and physiological activities. mGluR5 belongs to the Group I mGluRs and is coupled to inositol phosphate/ $\mathrm{Ca}^{2+}$ signal transduction pathway (Abe et al., 1992). mGluR5 has been demonstrated to have important roles in several forms of synaptic plasticity (Lu et al., 1997; Jia et al., 1998; Huber et al., 2000; Bikbaev et al., 2008) and learning behaviors (Lu et al., 1997; Chiamulera et al., 2001; Balschun and Wetzel, 2002), and has been suggested as a potential therapeutic target in several neurological disorders (Brody et al., 2004; Slassi et al., 2005; Marino and Conn, 2006; Dölen et al., 2007). mGluR5 is expressed throughout the CNS including in the hippocampus and lateral nucleus of the amygdala (Abe et al., 1992), which are both structures central to learning and memory mechanisms. Previous studies have demonstrated a role for mGluR5 in two very different forms of learning associated with the hippocampus and the amygdala. Systemic injection (Schulz et al., 2001) or local amygdala perfusion (Rodrigues et al., 2002) of mGluR5 antagonists can disrupt the acquisition of the fear response, and contextual fear conditioning is impaired in mice deficient for mGluR5 (Lu et al., 1997). Similarly mGluR5 knock-out mice show deficits in the acquisition of hippocampal dependent learning (Lu et al., 1997). Thus, while there

Received Dec. 1, 2008; revised Feb. 4, 2009; accepted Feb. 13, 2009.

This work was supported by grants from the National Institutes of Health-National Institute of Neurological Disorders and Stroke (5R01NS058894 to A.C. and NS28709 to S.F.H.). J.X. was supported by a National Alliance for Research on Schizophrenia and Depression Young Investigator Award. We thank Jelena Radulovic for comments on this manuscript.

Correspondence should be addressed to Jian Xu, The Salk Institute for Biological Studies, Molecular Neurobiology Laboratory, La Jolla, CA 92037. E-mail: jxu@salk.edu.

D01:10.1523/JNEUROSCI.5716-08.2009

Copyright $\odot 2009$ Society for Neuroscience $\quad$ 0270-6474/09/293676-09\$15.00/0 is significant evidence that mGluR5 is involved in the acquisition of new memories and synaptic plasticity mechanisms, the role of mGluR5 in one important aspect of learning is unknown: the reversal or extinction of a previously acquired task, an important adaptive process that corrects for an altered environmental or situation (Bouton, 1993). These learning mechanisms are important to retasking, and are particularly relevant to anxiety disorders in humans such as phobias and post-traumatic stress disorder (Barad, 2005). The mechanisms and molecules involved in these adaptive learning processes, which are often termed inhibitory learning (Bouton and Bolles, 1979; Bouton, 1993; Barad, 2005; Myers and Davis, 2007), are not fully understood, although both ionotropic and metabotropic glutamate receptors have been implicated (Walker et al., 2002; Callaerts-Vegh et al., 2006; Kim et al., 2007; Fendt et al., 2008).

In this study, we tested whether mGluR5 plays a role in inhibitory learning processes using newly generated mGluR5 knockout mice (supplemental Fig. 1, available at www.jneurosci.org as supplemental material). Toward this end, we tested mGluR5 knock-out mice in the acquisition and reversal of an associative conditioned task and a spatial reference task. In the classic pavlovian fear conditioning test, we found that mGluR5 null mice were impaired in the acquisition of fear conditioning, confirming a role for this receptor in neural circuits required for this form of learning (Lu et al., 1997; Rodrigues et al., 2002). Even more strikingly we observed a complete deficit in the ability of mGluR5 knock-out mice to extinguish the fear association in both a tonecued or context-cued test. In the MWM test, mGluR5 knock-out mice exhibited mild deficits in the rate of acquisition of the regular water maze task. However, when the task was reversed and mice were compelled to learn a new location for the escape platform, mGluR5 knock-out mice performed poorly in this novel situation. Together these findings demonstrate a significant role for mGluR5 in adaptive processes that underlie inhibitory learning. 


\section{Materials and Methods}

All experiments were approved by the Institutional Animal Care and Use Committees of the Salk Institute for Biological Studies.

Generation of mGluR5 knock-out mice. Standard gene targeting techniques were used to generate mutant floxed mGluR5 mice (supplemental Fig. 1, available at www.jneurosci.org as supplemental material). Genomic DNA for mGluR5 was cloned from a phage library of 129 SVJ mouse genomic DNA fragments (Stratagene). A cassette containing a neomycin resistance (neo) gene, flanked by loxP sites, under the control of the phosphoglycerol kinase (PGK) promoter was introduced into the intron 720 bp downstream of exon 7 (supplemental Fig. $1 a$, available at www.jneurosci.org as supplemental material). R1 embryonic stem cells (Nagy et al., 1993) were electroporated with the linearized targeting construct, maintained under G418 positive selection, and screened by Southern blot analysis for homologous recombination (supplemental Fig. 1b, available at www.jneurosci.org as supplemental material). Chimeric animals produced by injection of these cells into C57BL/6 blastocysts were bred with C57BL/6 mice, and germ-line transmission of the mutation was assessed by PCR and Southern blot. The neo cassette was removed in mice by crossing with transgenic mice with Cre recombinase under control of the protamine promoter (O'Gorman et al., 1997) to produce the floxed mice mGluR5 ${ }^{\text {loxP/loxP }}$ (supplemental Fig. $1 c-e$, available at www.jneurosci.org as supplemental material). Finally mGluR5 ${ }^{\text {loxP/loxP }}$ mice homozygous for the conditional allele were crossed to protaminecre mice to generate the mGluR5 knock-out mice (mGluR5 ${ }^{\mathrm{del} / \mathrm{del}}$ ).

Same sex littermates were housed 2-5 per cage, and maintained at $22^{\circ} \mathrm{C}$, with a $12 \mathrm{~h} \mathrm{light/dark} \mathrm{cycle.} \mathrm{mGluR5} 5^{\text {loxP/loxP }}$ and mGluR $5^{\text {del/del }}$ mice used in this study were produced by heterozygous breeding of mGluR5 $5^{\text {loxP/del }}$, or heterozygous breeding of mGluR5 $5^{\text {loxP/+ }}$ and mGluR $5^{\mathrm{del} /+}$. Age (2- to 4-month-old) and gender-matched littermates were used for behavioral studies.

Fear conditioning. An automated video tracking system was used to monitor mice in the fear conditioning paradigm (Med Associates). Samples were collected at the rate of 30 frames/s. A freezing event was registered only when activity was below motion threshold ( 20 arbitrary units) for at least $0.5 \mathrm{~s}$. Mice were handled daily for 1 week before the test and were transferred to a holding place adjacent to the testing room for 20 min to $1 \mathrm{~h}$ on the day of the test. The training on day $0(\mathrm{~d} 0)$ lasted for 6 min. Each mouse was subjected to either training paradigm A, that consisted of 3 min of baseline monitoring, followed by 3 pairs of 20 s tone ( 85 $\mathrm{db}, 2900 \mathrm{~Hz})$ coterminated with $1 \mathrm{~s}$ footshock $(0.7 \mathrm{~mA})$ given at $1 \mathrm{~min}$ intervals (Fig. 1a), or paradigm B, which was similar to the paradigm A except that the $1 \mathrm{~s}$ footshock was presented without the tone (Fig. $1 b$ ).

For contextual memory testing each mouse was returned to the same chamber with the exact contextual settings, but without tone and footshock and monitored for $6 \mathrm{~min}$. Chambers were cleaned with isopropanol between each set of mice (Fig. $2 a, \mathrm{~d} 1, \mathrm{~d} 15$ ). For the extinction of contextual memory the same procedure was repeated daily for 10 consecutive days (Fig. 3 ).

For testing auditory fear (Figs. $2 a, \mathrm{~d} 2, \mathrm{~d} 16 ; 4)$, the conditioning chamber was altered by covering the grid floor and the three sides with patterned plastic boards, and the top with colored paper. New visual cues were provided on the inside wall of the insulating box and on the walls of the testing room. The conditioning chamber was also scented with Windex and vanilla solution. Windex was used for cleaning after each testing. The testing lasted $6 \mathrm{~min}$ for each session. For the experiments presented in Figure 2 ( $\mathrm{d} 2$ and $\mathrm{d} 16$ ) each mouse was placed into the chamber for 3 $\mathrm{min}$ and three sets of $20 \mathrm{~s}$ tones were presented at $1 \mathrm{~min}$ intervals. For the extinction of auditory fear conditioning each mouse was put into the chamber for $3 \mathrm{~min}$ before the $3 \mathrm{~min}$ tone was presented. The same procedure was repeated daily for 16 consecutive days (Fig. 4).

Morris water maze. The Morris Water Maze experiments were conducted as previously described with some modifications (van Praag et al., 2005; Zhang et al., 2008). A white plastic water tank of $120 \mathrm{~cm}$ diameter was filled with water at room temperature. The water was made opaque with white nontoxic Crayola washable paint. A transparent platform ( 8 $\times 13 \mathrm{~cm}$ ) was submerged $1 \mathrm{~cm}$ below the surface of opaque water. An automated video tracking system (Ethovision; Noldus Information
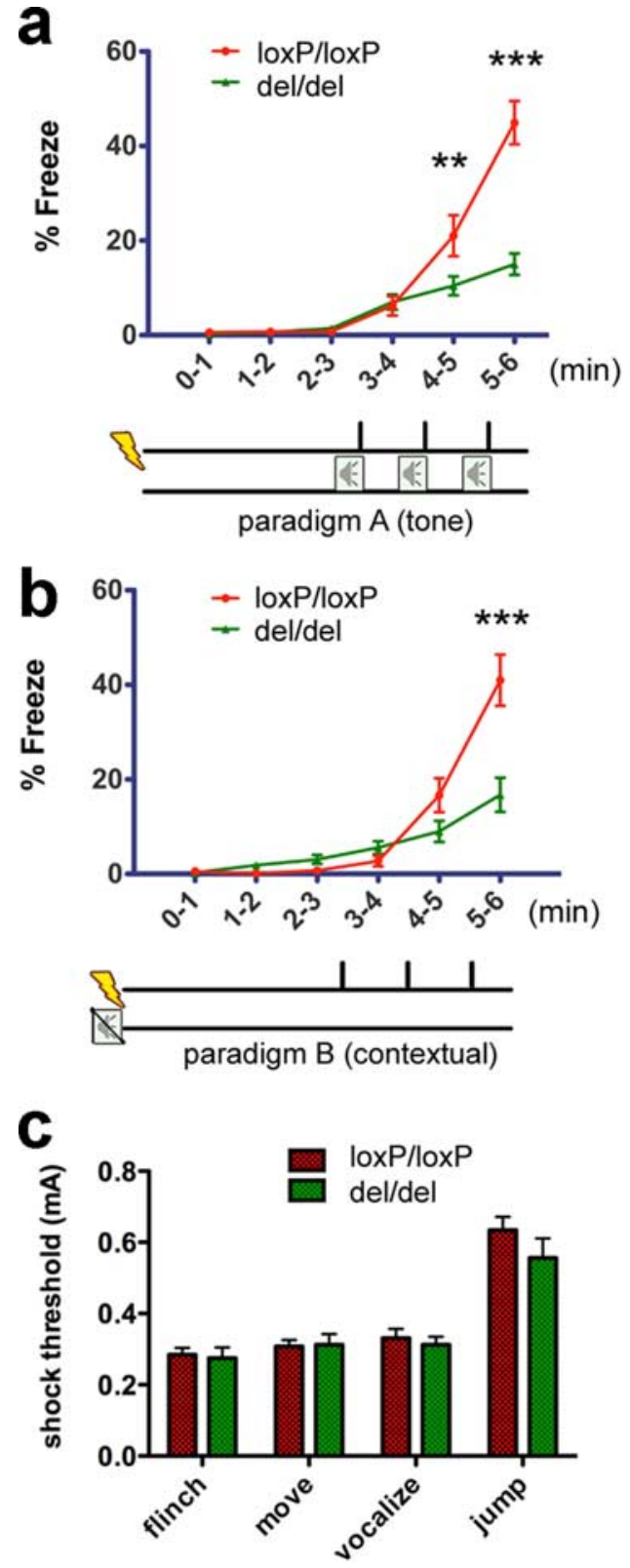

Figure 1. Deficits in fear acquisition in mice lacking mGluR5. $\boldsymbol{a}$, Fear acquisition by three footshocks paired with tones. mGluR5 ${ }^{\text {del/del }}$ mice $(n=28)$ froze significantly less than mGluR5 ${ }^{\text {loxP/loxP }}(n=27)\left(F_{(1,106)}=13.14, p=0.0006\right.$ for genotype; $F_{(2,106)}=33.93, p<$ 0.0001 for training - genotype interaction; Bonferroni post-tests for genotype, $p<0.05$ at $4-5$ $\min , p<0.0001$ at $5-6 \mathrm{~min}) . \boldsymbol{b}$, Fear acquisition by three footshocks. There was less freezing in mGluR5 ${ }^{\text {del/del }}$ mice $(n=20)$ than mGluR5 ${ }^{\text {loxP/loxP }}$ mice $(n=25)\left(F_{(1,86)}=6.31, p=0.0158\right.$ for genotype; $F_{(2,86)}=14.48, p<0.0001$ for training-genotype interaction; Bonferroni posttests for genotype, $p<0.0001$ at 5-6 min). c, Acute pain threshold to footshock was not altered in mGluR5 null mice. We measured the minimal currents required to elicit four stereotyped reactions against footshock: flinch, move, vocalization, and jump. mGluR5 ${ }^{\mathrm{del} / \mathrm{del}}$ mice $(n=8)$ and mGluR5 ${ }^{\text {loxP/loxP }}$ mice $(n=13)$ showed the same pain sensitivity to an increasing electric footshock ( $t$ test, $p>0.05$ for each reactions between genotypes). Data are presented as SEM ( ${ }^{* *} p<0.01,{ }^{* * *} p<0.001$ for Bonferroni post-tests).

Technology) was used to record the swim path, velocity and time taken to reach the platform (latency) or the time spent in each zone. The water maze procedure consisted of three phases: (1) visible platform training; (2) hidden platform training and probe test 1 ; and (3) reversed platform and probe test 2 .

Mice were first trained to find the visible platform for $3 \mathrm{~d}$ (three trials per day). A thin black plastic brick $(8 \times 13 \times 1.5 \mathrm{~cm})$ was placed above 
the transparent platform and a flag was installed $10-15 \mathrm{~cm}$ above the surface, allowing mice to visualize the location of the platform. Mice were released from the Southwest (SW) quadrant for all trials. The platform was rotated from the Northeast (NE) to Northwest (NW) to Southeast (SE) quadrant for each trial. Upon release, each mouse was allowed a maximum of $60 \mathrm{~s}$ to find the visible platform. Mice that failed to find the platform within $60 \mathrm{~s}$ were placed onto the platform. The mouse was allowed to remain on the platform for $15 \mathrm{~s}$ after each trial.

Hidden platform training was conducted one day after the completion of the visible platform training. Mice were trained for $7 \mathrm{~d}$ (three trials per day) to find the submerged platform at a fixed position (center of NE quadrant) without any visible local cues. Distal cues in the testing room, such as a computer desk and patterned cardboard on a white wall, were provided as spatial references. Each trial lasted either until the mouse found the platform, or for $60 \mathrm{~s}$. Starting points were changed every trial. Mice were allowed to rest on the platform for $15 \mathrm{~s}$ after each trial. The first probe trial was administered $24 \mathrm{~h}$ after the last trial of the hidden platform training. During the probe trial the mouse was allowed to swim for $60 \mathrm{~s}$ without the platform in the tank.

For the reverse platform training, the hidden platform was moved from the NE quadrant to the center of the SW quadrant without changing any distal visual cues. Mice were then trained to find this new platform location for $4 \mathrm{~d}$ (three trials per day). Day 1 of reverse training was conducted $2-3 \mathrm{~h}$ after the first probe test. Starting points were changed every trial. The second probe test was performed $7 \mathrm{~d}$ after the final training.

Statistical analysis. Statistical analyses were conducted with Graphpad Prism. For the multiple trial experiments including fear extinction tests and MWM tests, Two-way repeatedmeasures ANOVA was conducted to assess the effects of both genotype and sessions/trials. Bonferroni post hoc tests were conducted to compare genotype effects at individual session/ trial (Figs. 3b, 5a,b, 6a-c). Repeated measures one-way ANOVA were also conducted to assess the effects of training blocks/trials within the same genotype group. Dunnett's multiple comparison post-test was also performed to compare the means at individual time points to the control (first trial/block) (Fig. $6 a, b)$. Differences between two means presented in Figure $2 d-e$ were assessed with $t$ tests. Post-test for linear trend was performed to determine whether there is an increasing/deceasing trend in fear response during fear extinction tests (Figs. 3, 4). Data are presented as mean \pm SEM. Differences were considered significant if $p$ values were $<0.05$.

\section{Results}

To test whether mGluR5-deficient mice demonstrate memory or learning impairments we performed two learning and memory tasks: pavlovian fear conditioning and the Morris Water Maze (MWM) test. Pavlovian fear conditioning is a task in which a fear response to a neutral conditioned stimulus (CS) is learned when the CS is repeatedly paired with an aversive unconditioned stimulus (US) (LeDoux, 2000). In these experiments, the CS was either a context-specific environment or a loud tone $(85 \mathrm{db}, 2900$ $\mathrm{Hz}$ ) that was coupled to the US (footshock, $0.7 \mathrm{~mA}$ ). To deter- $\begin{array}{lllll}\text { d0 } & \text { d1 } & \text { d2 } & \text { d15 } & \text { d16 }\end{array}$

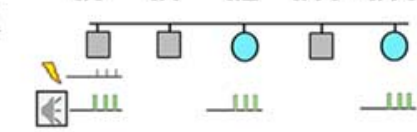

(paradigm A)
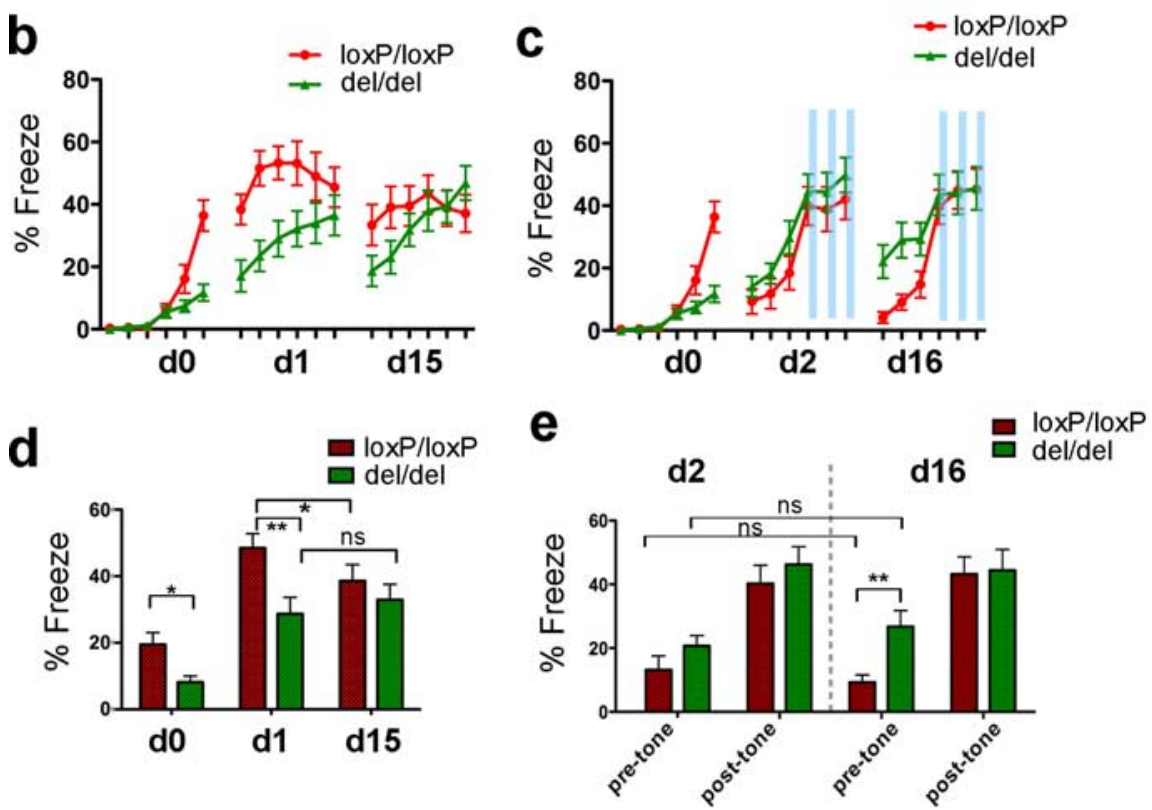

Figure 2. Effects of deleting mGluR5 on for both contextual and tone-cued fear conditioning. $\boldsymbol{a}$, The experimental paradigm. for $6 \mathrm{~min}$, with three pairs of $20 \mathrm{~s}$ tone presentations of $1 \mathrm{~min}$ intervals starting at $3 \mathrm{~min}$. $\boldsymbol{b}$, After fear acquisition at do,

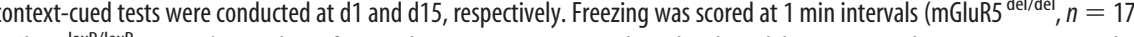
$, n=18)$. c, Auditory fear conditioning tests were conducted at $\mathrm{d} 2$ and d16, respectively. Freezing was scored at 1 min intervals (mGluR5 ${ }^{\text {del/del }}, n=17 ;$ mGluR5 $^{\text {loxP/loxP }}, n=18$ ). Time periods for tone presentations were highlighted with blue bars. $\boldsymbol{d}$, Freezing in $(\boldsymbol{b})$ was scored at 6 min intervals. mGluR5 ${ }^{\text {del/del }}$ mice exhibited $<50 \%$ postshock freezing (d0) compared with mGluR5 ${ }^{\text {loxP/loxP }}$ mice ( $p=0.0104, t$ test). In the first context test (d1) performed $24 \mathrm{~h}$ after training, mGluR5 ${ }^{\text {del/del }}$ mice showed a $40 \%$ reduction in the context-cued freezing time ( $p=0.0047, t$ test). The ratios of postshock

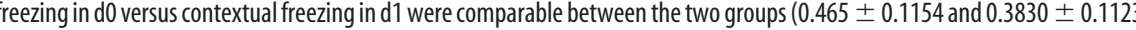
for mGluR5 ${ }^{\text {loxP/loxP }}$ and mGluR5 ${ }^{\text {del/del }}$ respectively; $p>0.05, t$ test). Contextual fear in the second test (d15) was slightly reduced mice ( $\mathrm{d} 1 \mathrm{vs} \mathrm{d} 15$; paired $t$ test, $p=0.047$ ), but was slightly increased in $\mathrm{mGluR5}{ }^{\text {del/ldel }}$ mice (d1 vs d15; paired freezing in the $(p=0.0028 t$ test). A significant difference was not detected between other genotype comparisons. Pretone freezing was reduced in $\mathrm{mGluR5} 5^{\text {loxP/loxP }}$ mice but was elevated in $\mathrm{mGluR5}{ }^{\text {del/del }}$ mice ( $\left.\mathrm{d} 2 \mathrm{vs} \mathrm{d} 16\right)$, but the differences were not significant. Data are presented as SEM $\left({ }^{*} p<0.05,{ }^{* *} p<0.01\right.$, for $t$ tests).

mine whether ablation of mGluR5 affects acute acquisition of fear, animals were presented with three pairings of the CS and US (Fig. 1a, paradigm A). mGluR5 ${ }^{\text {loxP/loxP }}$ mice displayed immediate postshock freezing that progressively increased after repeated presentations of CS-US. mGluR5 ${ }^{\mathrm{del} / \mathrm{del}}$ mice froze after footshocks, but the increment in freezing behavior was significantly lower in comparison with the control group upon repeated trials (Fig. 1a). mGluR5 ${ }^{\mathrm{del} / \mathrm{del}}$ mice were also impaired in a second training paradigm in which mice were given three footshocks without the presentation of the tone (Fig. 1b, paradigm B). Thus, acquisition of fear is impaired in mice lacking mGluR5. This impairment is unlikely to be caused by reduced pain sensitivity to electric footshock because mGluR5 ${ }^{\mathrm{del} / \mathrm{del}}$ mice showed the same pain response as $\mathrm{mGluR} 5^{\text {loxP/loxP }}$ mice (Fig. 1c).

Next, we tested whether mGluR $5^{\text {del/del }}$ mice retained contextual cued and auditory fear memories. In the first context test performed $24 \mathrm{~h}$ after training $(\mathrm{d} 1)$ in paradigm $\mathrm{A}, \mathrm{mGluR} 5^{\mathrm{del} / \mathrm{del}}$ mice showed a significant reduction in the context-cued freezing 

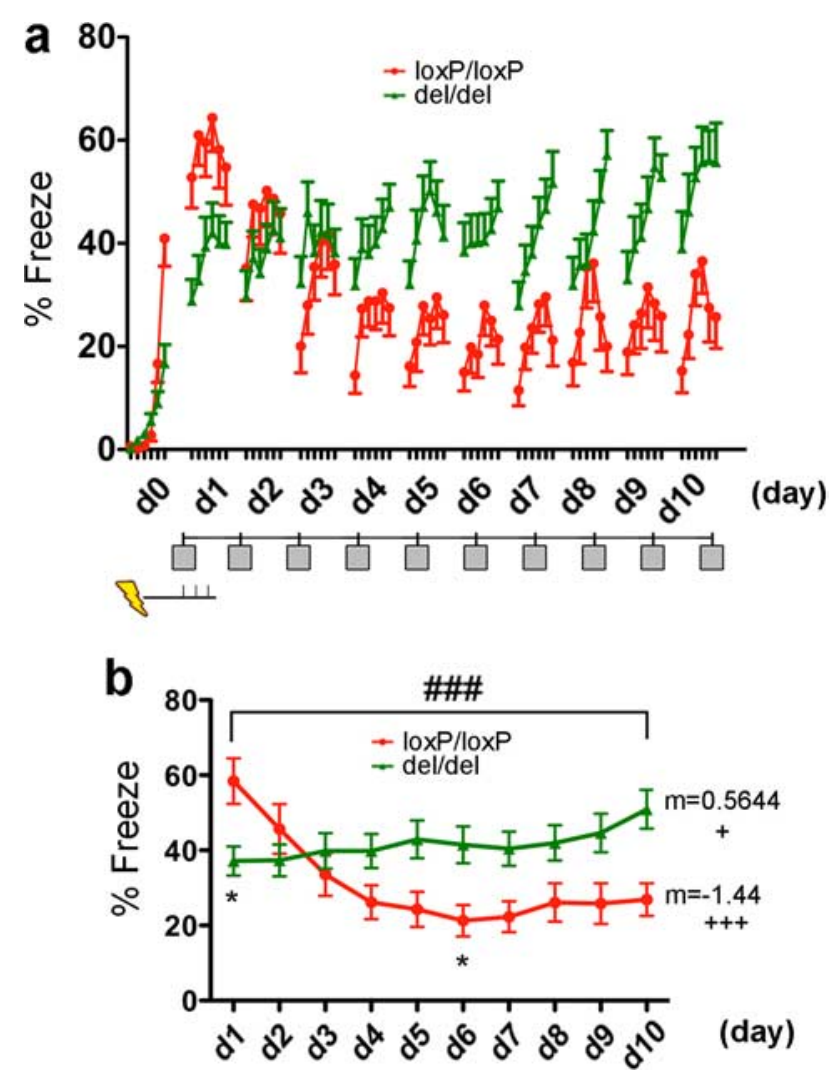

Figure 3. Contextual fear extinction was abolished in mGluR5-deficient mice. $\boldsymbol{a}$, Extinction of contextual fear. Mice [mGluR5 ${ }^{\text {del/del }}, n=20$ (d1-d9), $n=14$ (d1-d10); mGluR5 loxP/loxP, $n=25(\mathrm{~d} 1-\mathrm{d} 7), n=15,(\mathrm{~d} 1-\mathrm{d} 10)]$ were trained in $\mathrm{d} 0$ with three footshocks and returned to the same context (marked by gray box) up to 10 consecutive days for 6 min each day. Freezing was analyzed at 1 min intervals. During extinction training (d1-d10), mGLuR5 ${ }^{\text {loxP/loxP }}$ mice generally showed bell-shaped time-response with highest freezing occurring at 3-4 min, whereas $\mathrm{mGluR5}{ }^{\mathrm{del} / \mathrm{del}}$ mice showed a trend of increase freezing toward the end of $6 \mathrm{~min}$ training session. $\boldsymbol{b}$, Freezing in $\boldsymbol{a}$ was scored at 6 min intervals. $\mathrm{mGluR} 5{ }^{\mathrm{del} / \mathrm{del}}$ mice displayed no extinction over the trials (nonmatching two-way ANOVA, $F_{(1,394)}=21.26, p<0.0001$ for genotype; $F_{9,394}=4.22, p<0.0001$ for day- genotype interaction; Bonferroni post-tests for genotype, ${ }^{*} p<0.05$ at $\mathrm{d} 1$ and d6). For the mGluR5 ${ }^{\text {loxP/loxP }}$ group, one-way ANOVA detected significant effect of training $\left(F_{(9,210)}=6.644, p<0.0001\right)$. Post-test further detected significant trend of fear extinction (slope $=-1.44, p<0.0001$ ). For the $\mathrm{mGluR5} 5$ del/del group, effect of training was not significant by one-way ANOVA $\left(F_{(9,184)}=0.61, p>0.05\right)$. However, posttest for liner trend detected a significant positive trend (slope $=0.57, p=0.036$ ). Data are presented as SEM ( ${ }^{*} p<0.05$, for Bonferroni post-tests; ${ }^{\# \#} p<0.001$ for two-way ANOVA). (Linear slope is denoted by " $\mathrm{m}$ "; $^{+} p<0.05$ and ${ }^{+++} p<0.001$ for ANOVA post-test for linear trend). ns, Not significant.

time (Fig. $2 b$, in $\mathrm{d} 1$ ). The fractions of context-cued freezing were $0.49 \pm 0.04$ and $0.29 \pm 0.05$ for $\mathrm{mGluR} 5^{\text {loxP/loxP }}$ mice and mGluR5 ${ }^{\text {del } / \mathrm{del}}$ mice respectively (Fig. $\left.2 d\right)(p=0.0047, t$ test). However, the ratio of freezing during acquisition ( $\mathrm{d} 0)$ to $\mathrm{d} 1 \mathrm{was}$ comparable between the two groups $(0.47 \pm 0.12$ and $0.38 \pm 0.11$ for $\mathrm{mGluR} 5^{\text {loxP/loxP }}$ and $\mathrm{mGluR} 5^{\mathrm{del} / \mathrm{del}}$ respectively; $p>0.05, t$ test), suggesting that although mGluR $5^{\text {del/del }}$ mice are impaired in the initial fear acquisition, they retain the ability to express the once-memorized fear response. In contrast to this contextspecific deficit, we found that $24 \mathrm{~h}$ later (d2) when mice were subjected to the CS tone-cued test, both groups showed similar pretone freezing (Fig. $2 c, e ; 0-3 \mathrm{~min}$ in $\mathrm{d} 2$ ) and post-tone freezing (Fig. $2 c, e ; 4-6 \mathrm{~min}$ in $\mathrm{d} 2$ ). Therefore $\mathrm{mGluR} 5^{\mathrm{del} / \mathrm{del}}$ mice are able to remember the association between the CS and US $2 \mathrm{~d}$ after training. To determine the retention of these memories at later time points, mice were tested again after 2 weeks ( 115 and $\mathrm{d} 16)$. Contextual fear (d15) was slightly reduced in mGluR5 ${ }^{\text {loxP/loxP }}$ mice (paired $t$ test, $p=0.044$ ) but was slightly increased in mGluR5 ${ }^{\text {del/ldel }}$ mice (paired $t$ test, $p>0.05$ ) (Fig. $2 b, d$, compare $\mathrm{d} 1, \mathrm{~d} 15)$. In the second CS tone-cued test conducted in $\mathrm{d} 16$, both groups displayed similar post-tone freezing (Fig. $2 c, e$ in d16). Noticeably, however, pretone freezing $(0-3 \mathrm{~min})$ was reduced in mGluR5 ${ }^{\text {loxP/loxP }}$ mice but was elevated in mGluR5 ${ }^{\mathrm{del} / \mathrm{del}}$ mice, although these differences were not significant (Fig. 2e, compare $\mathrm{d} 2, \mathrm{~d} 16)$. Pretone freezing in the second auditory fear memory test was 2.5 times greater in $\mathrm{mGluR} 5^{\mathrm{del} / \mathrm{del}}$ mice than the control group (Fig. $2 e, \mathrm{~d} 16)(p=0.0028, t$ test), suggesting that mGluR5 ${ }^{\text {del/del }}$ mice became less discriminative to the fear environment compared with the control group after training.

A previously learned aversive association can be suppressed or extinguished by repeated presentation of the CS in the absence of the US. With this training the animal learns that the CS no longer predicts the US such that the fear response is "inhibited." The most widely accepted theory for the neural basis of extinction is that it is a parallel process distinct from fear acquisition and is often termed inhibitory learning (Bouton and Bolles, 1979; Bouton, 1993; Barad, 2005; Myers and Davis, 2007). This is a distinct mechanism from when extinction is performed very shortly after acquisition of the fear association, when it may be a reversal or unlearning process (Myers et al., 2006). To determine whether inhibitory learning requires mGluR5 we performed fear extinction studies. In the first experiment, mice were trained with paradigm $B$ in which they learn to associate the footshock with a context. Mice were then returned to the same context everyday without footshock for 10 consecutive days (Fig. 3a). Freezing in mGluR $5^{\text {loxP/loxP }}$ mice decreased during the extinction training, as revealed by one-way ANOVA $\left(F_{(9,210)}=5.644, p<0.0001\right)$ (Fig. $3 b$ ). Dunnett's multiple comparison test revealed a significant difference between day 1 and all subsequent days. In addition, the post-test for linear trend revealed a significant decreasing trend in freezing during the period of extinction training in mGluR $5^{\text {loxpP/ }}$ loxp mice (slope $=-1.438, p<0.0001$ ). In contrast to this, fear extinction in mGluR5 ${ }^{\mathrm{del} / \mathrm{del}}$ mice was completely abolished (Fig. $3 a$ ). One-way ANOVA comparison did not detect any effects of extinction training for mGluR5 ${ }^{\mathrm{del} / \mathrm{del}}$ mice $\left(F_{(9,184)}=0.7882, p>\right.$ 0.05 ) (Fig. $3 b$ ). In fact, mGluR $5^{\mathrm{del} / \mathrm{del}}$ mice exhibited a slightly increased amount of freezing on $\mathrm{d} 10(51 \pm 5.2 \%)$ than on the first day $(\mathrm{d} 1)(37 \pm 3.9 \%)$, although the difference did not reach significance (by Dunnett's post-tests analysis). The post-test for linear trend revealed a significant increasing trend in freezing for mGluR $5^{\mathrm{del} / \mathrm{del}}$ mice $($ slope $=0.5644, p=0.0036$ ). These experiments are the first to demonstrate a substantial role for mGluR5 in contextual fear extinction.

Next, to determine whether a similar deficit might be observed in extinction of auditory fear, we performed a separate series of experiments. Mice were first trained in paradigm A (tone-cued test), and were then tested in a different context without footshock but with tone presentation for 16 consecutive days. There was a clear difference between mGluR $5^{\operatorname{loxP} / \operatorname{lox} P}$ and mGluR $5^{\text {del/del }}$ animals in the extinction of both pretone and posttone fear (Fig. 4a). To better assess fear behaviors, freezing was analyzed in four categories: total freezing (0-6 min) (Fig. $4 b)$, pretone freezing $(0-3 \mathrm{~min})$ (Fig. $4 d)$, post-tone freezing $(4-6$ min) (Fig. 4e) and tone-cued freezing (post-tone freezing minus pretone freezing) (Fig. 4c). Although initially mGluR5 ${ }^{\text {del/del }}$ mice showed less post-tone freezing than control mice (Fig. 4e), this freezing behavior did not diminish during the course of repeated daily exposure to the tone. The control group showed a clear reduction in post-tone freezing which was significant between days 9 and 16 of extinction training (Fig. 4e). Both groups dis- 
played similar amount of pretone freezing between days 1 and 9 of training (Fig. $4 d$ ). However as training progressed there was a steady reduction of pretone freezing in mGluR5 ${ }^{\text {loxP/loxP }}$ mice whereas mGluR5 ${ }^{\text {del/ }}$ del mice continued to display the same degree, or increased, pretone freezing during the late stages of extinction training (Fig. $4 d)$. To further examine the freezing response as a more direct result of the tone cue, we subtracted pretone freezing from post-tone freezing and presented it as tone-cued fear in Figure $4 c$. At the onset $(\mathrm{d} 1-\mathrm{d} 5)$, tone-cued freezing was lower in mGluR5 del/del mice compared with the control group, which displayed the most robust freezing on the second and third day (Fig. 4c). However, tone-cued freezing was progressively reduced in mGluR5 ${ }^{\text {loxP/loxP }}$ group, while it was maintained at a similar level throughout the test in mGluR $5^{\text {del/del }}$ mice. Near completion of the test $(\mathrm{d} 9-\mathrm{d} 16)$, tone-cued freezing was no longer different between the two genotypes groups (Fig. 4c). Overall, there was a significant trend in the decrease of the fear curve in mGluR5 $5^{\text {loxP/loxP }}$ mice (slope $=$ $-0.29, p<0.0031)$, but not in mGluR5 ${ }^{\mathrm{del} / \mathrm{del}}$ mice (slope $=0.10, p=0.23$ ) (Fig. $4 c$ ). Finally, comparing total freezing revealed the opposite trends between mGluR $5^{\text {loxP/loxP }}$ mice and the mGluR5 ${ }^{\text {del/del }}$ mice: no difference in the early part of the test, and significant differences later (Fig. $4 b$ ). Together these data demonstrate that mice lacking mGluR5 were not able to extinguish tone-cued fear (Fig. 4c) and became less able to discriminate the fear environment (Fig. 4d) during the course of extinction training. Notably, even the extinction of pretone freezing in the control group was much slower compared with the extinction of context-cued freezing shown in Figure 3; although it might be expected that pretone freezing should stay at relatively low levels when the mice were exposed to a neutral context. A likely explanation for this is that during the extinction training, the mice learned to associate the neutral environment to tone, which they had previously associated to the US (footshocks). In support of this idea, extinction of pretone freezing correlated very well with the extinction of post-tone freezing for both genotype groups, suggesting that the original neutral environment had become another CS for fear.

We also conducted a control experiment to examine whether presentation of the $85 \mathrm{db} 2900 \mathrm{~Hz}$ tone alone, without footshock, could cause freezing in mice. We found that an $85 \mathrm{db}$ tone lasting for $3 \mathrm{~min}$ induced little freezing in mice $(<3 \%$ in both groups, see supplemental Fig. 3, available at www.jneurosci.org as supplemental material). Therefore the in-
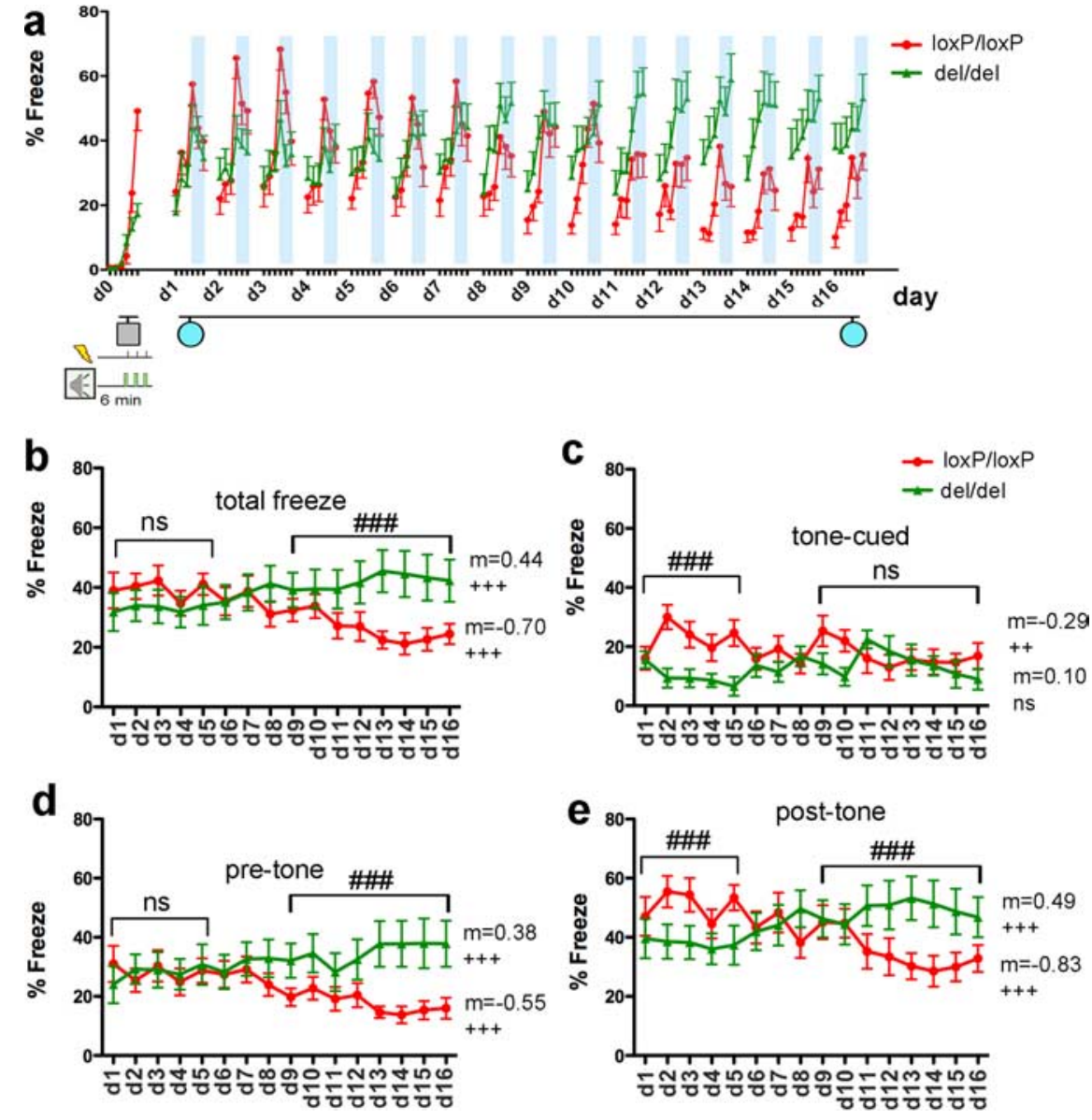

Figure 4. Extinction of auditory fear conditioning was abolished in mGluR5-deficient mice. $\boldsymbol{a}$, Extinction of auditory fear conditioning. Mice were trained with three footshocks paired with tones at do in one context (gray square) and subsequently returned to a different context (blue circles) for 16 consecutive days. Extinction training on each day lasted 6 min, with one tone of $3 \mathrm{~min}$ presented during the final $3 \mathrm{~min}$. Freezing was scored at $1 \mathrm{~min}$ intervals to compare within-session fear expression profiles between the two genotype groups ( $\mathrm{mGluR} 5{ }^{\mathrm{del} / \mathrm{del}} n=14 ; \mathrm{mGluR} 5^{\operatorname{loxP} / \mathrm{loxP}} n=16$ ). Time periods for the tone presentations were highlighted with blue bars (each represents $3 \mathrm{~min}$ ). Gray square marked for the context for fear acquisition. Blue circles indicate the neutral context where extinction trainings were conducted. $\boldsymbol{b}$, Total freezing in each day analyzed in 6 min block. Initially, mGluR5 ${ }^{\text {del/del }}$ mice $(n=14)$ showed slightly less freezing $\left(F_{(1,140)}=3.86, p=0.0513, \mathrm{~d} 1-\mathrm{d} 5\right)$, but this freezing behavior was not diminished during the course of repeated tone presentations. In contrast, $\mathrm{mGluR} 5^{\mathrm{loxP} / \mathrm{loxP}}$ mice $(n=16)$ showed extinction of auditory fear conditioning upon repeated daily exposure, resulting in less freezing in the second half of testing $\left(F_{(1,224)}=32.64\right.$, $p<0.001, \mathrm{~d} 9-\mathrm{d} 16)$. Overall, day- genotype interaction was significant $\left(F_{(15,420)}=7.52, p<0.0001\right)$. Post-test detected significant trend of fear extinction in $\mathrm{MGluR} 5^{\mathrm{loxP} / \mathrm{loxP}}$ mice (slope $=-0.70, p<0.0001$ ) and significant trend of increase in fear in mGluR5 ${ }^{\mathrm{del} / \mathrm{del}}$ mice (slope $\left.=0.44, p<0.0001\right)$. c, Extinction of tone-cued freezing. At the onset, tone-cued freezing was less in mGluR5 ${ }^{\text {del/del }}$ mice $\left(F_{(1,140)}=29.57, p<0.0001, \mathrm{~d} 1-\mathrm{d} 15\right)$. Near the completion of the test, tone-cued freezing amounts were similar between the two groups $\left(F_{(1,224)}=2.16, p=0.14, \mathrm{~d} 9-\mathrm{d} 16\right)$. Tw0-way ANOVA showed a significant day-genotype interaction from d1 to d16 $\left(F_{(15,420)}=2.80, p=0.0004\right)$. Post-test for linear trend detected significant trend of decrease of fear in $\mathrm{mGluR5} 5^{\text {loxP/loxP }}$ mice (slope $=-0.29, p<0.0031$ ) but not in $\mathrm{mGluR5}{ }^{\mathrm{del} / \mathrm{del}}$ mice (slope $=0.11, p=0.23$ ). $\boldsymbol{d}$, Pretone freezing analyzed in $3 \mathrm{~min}$ block. Although both groups displayed similar amounts of freezing in the early and middle sessions of training $(\mathrm{d} 1-\mathrm{d} 9)$, mGluR5 ${ }^{\mathrm{del} / \mathrm{del}}$ mice froze more in the late sessions (d9-d16) $\left(\mathrm{F}_{1,224}=40.15, p<0.0001\right)$. Two-way ANOVA showed a significant day-genotype interaction from d1 to d16 $\left(F_{(15,420)}=4.13, p<0.0001\right)$. Post-test for linear trend detected

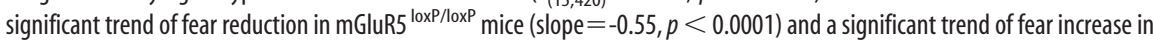
mGluR5 ${ }^{\text {del } / \text { del }}$ mice (slope $\left.=0.38, p<0.0001\right)$. e, Post-tone freezing analyzed in 3 min block. Initially, post-tone freezing was less in mGluR5 ${ }^{\text {del/del }}$ mice $\left(F_{(1,140)}=12.87, p=0.0005, \mathrm{~d} 1-\mathrm{d} 15\right)$. However, mGluR5 ${ }^{\text {del } / \text { del }}$ mice froze more in the end $\left(F_{(1,224)}=\right.$ $20.2, p<0.0001, \mathrm{~d} 9-\mathrm{d} 16)$. Tw0-way ANOVA showed a significant day-genotype interaction from d1 to d16 $\left(F_{(15,420)}=7.50\right.$, $p<0.0001)$. A significant trend of fear reduction in mGluR5 ${ }^{\text {del/del }}$ mice $(m=-0.83, p<0.0001)$ and a significant trend of fear increase in mGluR5 ${ }^{\text {del/del }}$ mice $(m=0.49, p<0.0001)$ were detected. Data are presented as SEM ( ${ }^{\# \# \# ~} p<0.001$ for two-way ANOVA). (Linear slope is denoted by "m"; ${ }^{++} p<0.01$ and ${ }^{+++} p<0.001$ for ANOVA post-test for linear trend). ns, Not significant.

fluence of this freezing in our experiments is small, and unlikely to confound our conclusions.

In the next series of experiments we determined whether mGluR5 ${ }^{\text {del/del }}$ mice demonstrated a deficit in spatial learning in the standard MWM test. A previous study had found that 
a
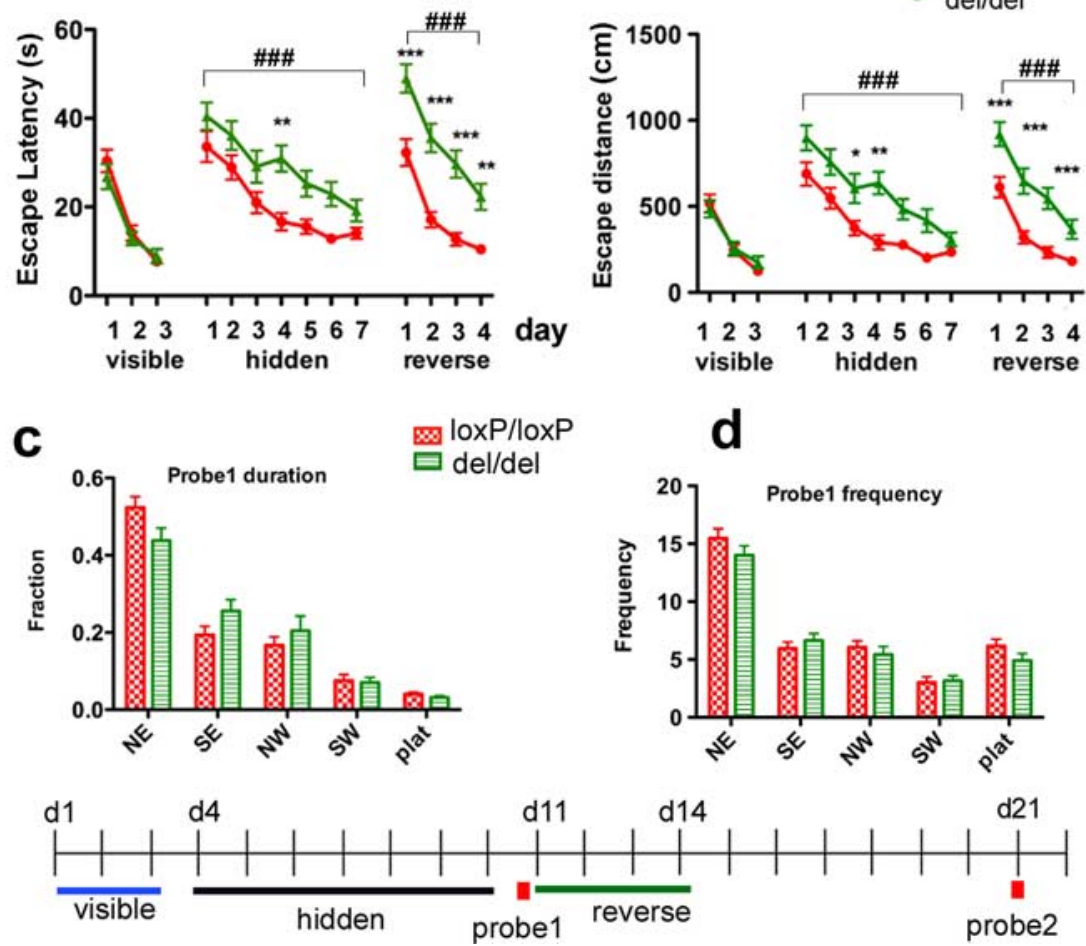

Figure 5. Deleting mGluR5 impaired performance in the MWM. The water maze procedure consisted of three phases: (1) visible platform training, $\mathrm{d} 1-\mathrm{d} 3$; (2) hidden platform training and probe test 1, d4 - d11; and (3) reversed platform and probe test $2, \mathrm{~d} 11-\mathrm{d} 21$. The experimental paradigm is illustrated at the bottom of the figure. $\boldsymbol{a}, \boldsymbol{b}$, Escape times $(\boldsymbol{a})$ and path lengths $(\boldsymbol{b})$ taken to reach the platform. Escape times and path lengths were analyzed by training block ( 3 trials per day). In the visible platform test, both groups learned the task, as indicated by incremental reductions in escape times $\left(F_{(2,72)}=82.31, p<0.0001\right)$ and distances $\left(F_{(2,72)}=53.91, p<0.0001\right)$ during training. There was no significant difference in either escape times $\left(F_{(1,72)}=0.36, p=\right.$ $0.5499)$ or path lengths $\left(F_{(1,72)}=0.07, p=0.7951\right)$ between genotype groups (mGluR5 ${ }^{\text {del/del }}, n=19 ;$ mGluR5 $\left.^{\text {loxP/loxP }} n=19\right)$ in the visible platform test (left block). Mice were then trained to find a hidden platform during the next seven consecutive days ( 3 trials per day). mGluR5 ${ }^{\text {del/del }}$ mice consistently showed a longer escape latencies and path lengths (middle block) over the training blocks. Repeated-measure two-way ANOVA showed a significant effect of genotype $\left(F_{(1,216)}=15.49, p=0.0004\right)$ and day $\left(F_{(6,216)}=21.59, p<0.0001\right)$ but not of the genotype-day interaction $\left(F_{(6,216)}=0.83 p=0.5494\right)$ on escape latency. Bonferroni post-tests detected significant differences at hidden day $4,{ }^{* *} p<0.01$. Similarly, there were significant effects of genotype $\left(F_{(1,216)}=23.99, p<0.0001\right)$ and day $\left(F_{(6,216)}=26.44, p<0.0001\right)$ but not genotype- day interaction $\left(F_{(6,216)}=\right.$ $1.17, p=0.3236$ ) on escape length (Bonferroni post-tests for genotype, ${ }^{*} p<0.05$ hidden day $3,{ }^{* *} p<0.01$, hidden 4 ). A probe test was conducted $24 \mathrm{~h}$ after the completion of regular platform training $(\boldsymbol{c}, \boldsymbol{d})$. Immediately after the first probe test, the platform was removed to the opposite quadrant in the pool and mice were trained at three trials per day for another $4 \mathrm{~d}$ in this reversed setting. Although both groups acquired the task after $4 \mathrm{~d}$ training, mGluR5 ${ }^{\text {del/del }}$ mice demonstrated longer escape time (Fig. $5 a$, right block) $\left(F_{(3,108)}=42.38, p<0.0001\right.$ for day; $F_{(1,108)}=45.68, p<0.0001$ for genotype; $F_{(3,108)}=0.80, p=0.4978$ for day-genotype interaction; Bonferroni post-tests, $p<0.001$ for reverse day 1 and day $3, p<0.01$ for reverse day 4$)$, and path lengths (Fig. 5b, right block) $\left(F_{(3,108)}=36.59, p<0.0001\right.$ for day; $F_{(1,108)}=35.52, p<0.0001$ for genotype; $F_{(3,108)}=0.90$, $p=0.4418$ for day-genotype interaction; Bonferroni post-tests, $p<0.001$ for reverse day 1 , day 2 , and day $3, p>0.05$ for reverse day 4). $\boldsymbol{c}, \boldsymbol{d}$, Performances in the first probe test. The first probe test was conducted $24 \mathrm{~h}$ after the completion of regular platform training. Analysis of the time spent in the four quadrants (c) revealed a significant effect of quadrant $\left(F_{(4,144)}=86.20\right.$, $p<0.0001$ ). mGluR5 ${ }^{\text {loxP/loxP }}$ mice spent slightly more time in the target quadrant (NE) and platform zone than mGluR5 ${ }^{\text {del/del }}$. However, the genotype- quadrant interaction was not significant $\left(F_{(4,144)}=2.24, p=0.0678\right)$. Further analysis of times entered in each testing zone $(\boldsymbol{d})$ also revealed a significant effect of quadrant $\left(F_{(4,144)}=125.02, p<0.0001\right)$. Entries to $\mathrm{NE}$ quadrant and platform zone were slightly higher in $\mathrm{MGluR5} 5^{\text {loxP/loxP }}$ mice compared with $\mathrm{mGluR5}{ }^{\text {del/del }}$ mice, but the genotype-quadrant interaction was not significant $\left(F_{(4,144)}=1.33, p=0.2615\right)$. Data are presented as SEM $\left({ }^{*} p<0.05,{ }^{* *} p<0.01,{ }^{* * *} p<0.001\right.$ for Bonferroni posttests; ${ }^{\# \# \#} p<0.001$ for two-way ANOVA).

mGluR5 null mice had a robust deficit in performance in this test (Lu et al., 1997). In contrast we found only a mild impairment in performance of mGluR5 ${ }^{\text {del/del }}$ mice in the MWM. During the first 3 experimental days, mice were trained to find a visible platform, and both groups performed equally on this task, suggesting that mutant and control mice could visualize the platform and swim equally effectively (Fig. $5 a, b$, left). During the next seven experimental days, mice were trained to find a hidden platform (three trials per day) (Fig. 5a,b, middle). Although both groups acquired the task during training, mGluR $5^{\text {del/del }}$ mice consistently showed longer escape latencies and path lengths over the training blocks. These disparities were not caused by differences in swim speed. In fact, mGluR5 ${ }^{\text {del/del }}$ mice swam slightly faster during hidden platform training (supplemental Fig. 2, available at www.jneurosci. org as supplemental material). We next performed a probe trial in which the platform was removed from the learned location. The first probe test conducted $24 \mathrm{~h}$ after the initial training demonstrated that both groups remembered the location of the platform (Fig. $5 c, d$ ). mGluR $5^{\operatorname{lox} / / \operatorname{lox} P}$ slightly outperformed mGluR $5^{\mathrm{del} / \mathrm{del}}$ by spending more time in the target quadrant (NE) and the platform zone (Fig. 5c). However, the genotype-by-quadrant interaction was not significant. mGluR $5^{\text {loxP/ }}$ loxP also made slightly more entries to the target quadrant and the platform zone than mGluR $5^{\text {del/del }}$ (Fig. $5 d$ ), but again, the genotype-by-quadrant interaction was not significant.

In the final test we performed a reversal of the hidden platform in the MWM. Immediately after probe test 1 , the platform was moved to the opposite quadrant location (SW) and mice were trained for $4 \mathrm{~d}$ (three trials per day) in this reversed setting. mGluR5 ${ }^{\mathrm{del} / \mathrm{del}}$ mice showed significantly longer escape times (Fig. $5 a$, right) and path lengths (Fig. 5b, right) over the training blocks. When data were analyzed by trials, the group differences were more evident in early training, with significant differences between the genotypes occurring in both latency and distance as early as the second and third trial (Fig. 6a,b). While mGluR $5^{\mathrm{del} / \mathrm{del}}$ mice continued to return to the previous target location, the control cohort more rapidly found the platform in the new location (Fig. $6 d$, representative tracks taken from trial 2). Throughout this training, mGluR5 $5^{\text {del/del }}$ mice entered the NE (previous target location) more often then the control group (Fig. $6 c$ ). Meanwhile, the number of entries into the SE and NW (no platform zone) quadrants were much lower for mGluR $5^{\mathrm{del} / \mathrm{del}}$ mice, and were comparable between mGluR5 ${ }^{\text {del/del }}$ and mGluR5 $5^{\text {loxP/loxP }}$ mice

(Fig. 6c). These results demonstrate that a persistent search in the previous target zone resulted in a significant delay for mGluR 5 del/del mice to find the new target location. The second probe test in which the platform was again removed was conducted after a further $7 \mathrm{~d}$ and revealed no differences in performance between groups (Fig. $6 e, f)$. Thus, spatial memory was intact in mice lacking mGluR5, whereas mice had a clear deficit in the reversal task. These experiments further support a role of mGluR5 in inhibitory learning. 


\section{Discussion}

Previous work has highlighted a role for mGluR5 in learning and memory, and in various forms of synaptic plasticity. In the present study we generated a novel strain of mGluR5 mutant mice to test the role of mGluR5 in two common learning paradigms, fear conditioning and the MWM. We found that mGluR5 plays a role in the initial steps of memory acquisition rather than memory storage and retrieval. mGluR5-deficient mice were defective in the acquisition of fear conditioning. However, they retained the ability to express the once-memorized fear response (Fig. 2). Similarly, mGluR5-deficient mice displayed mild impairments in the acquisition of the standard of version of the MWM, but were able to remember the location of the hidden platform during the probe test (Fig. 5). Together these findings suggest that mGluR5 mutant mice are defective in the acquisition, rather than the retention and retrieval of the memories. These findings are consistent with prior studies which have demonstrated a role for mGluR5 in the acquisition of fear and spatial memories (Schulz et al., 2001; Rodrigues et al., 2002).

Our study is not the first to generate mGluR5 knock-out mice. The mice used here were generated as conditional allele mutations to eventually allow ablation of mGluR5 in a spatial and temporally restricted pattern. In a prior study a conventional global knock-out allele of mGluR5 was generated (Lu et al., 1997). In behavioral test these mice were impaired in contextual fear conditioning and acquisition of the standard MWM task in agreement with our finding with mGluR $5^{\mathrm{del} / \mathrm{del}}$ mice. In contrast to the prior study, in our experiments we found only mild impairments in the acquisition of spatial learning in the MWM whereas Lu et al., had reported more robust deficits in this form of learning. Notably, in both studies similar deficits were observed in acquisition during the early trial blocks. Knock-out mice displayed progressive learning during these early trial blocks, although their escape latencies were longer than the control groups. The main discrepancy between our findings and the prior study arise in the late training blocks. In the previous study, mGluR5 knock-out mice were unable to improve their performance further in the MWM task in late trial blocks. Their escape latencies leveled at 35-40 s throughout the rest of the training [ $\mathrm{Lu}$ et al. (1997), their Fig. 5]. In our experiments, our knock-out mice had a steady increase in learning throughout all the
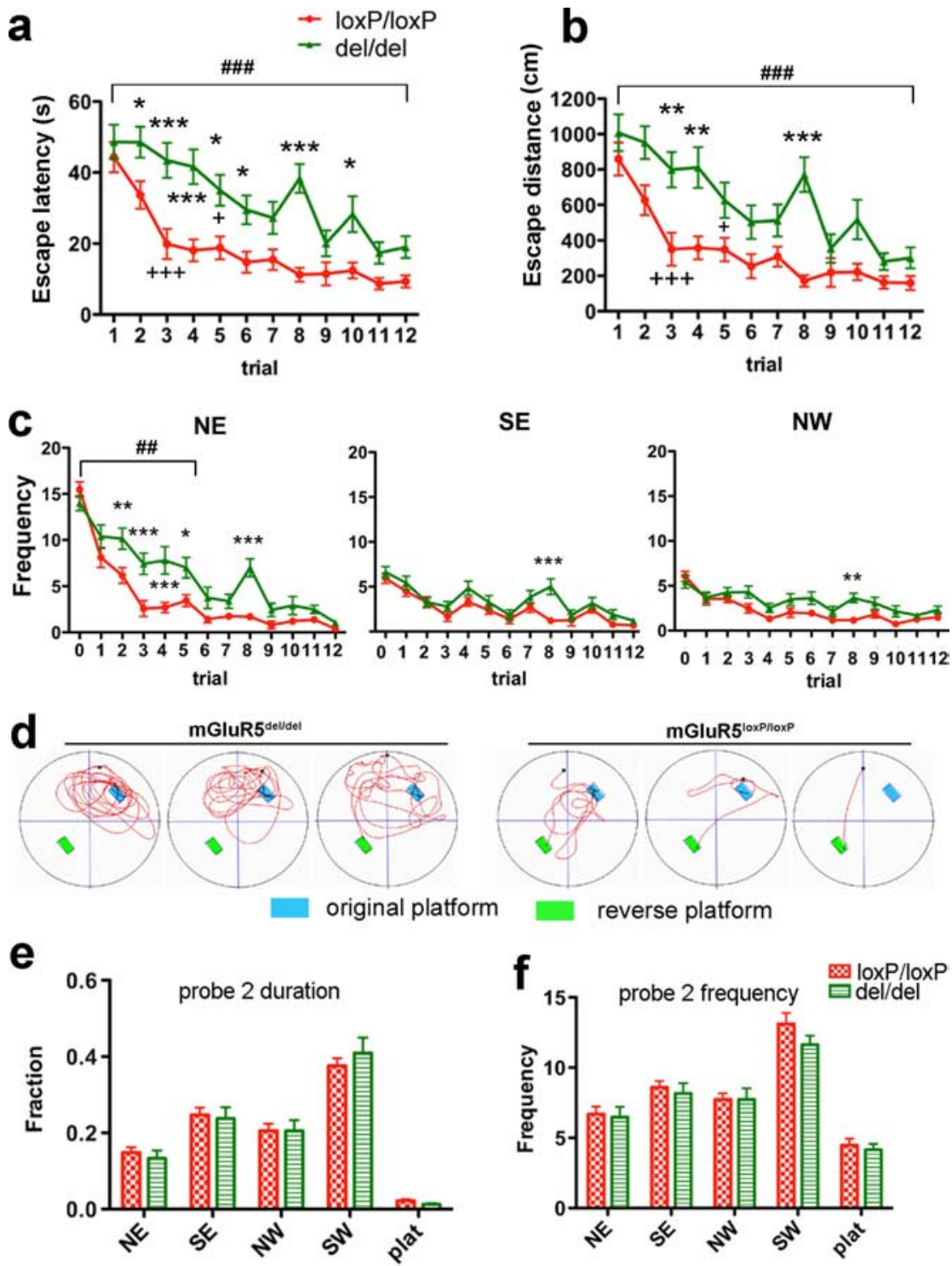

Figure 6. Ablation of mGluR5 caused a significant deficit in performance of the reversal task of the MWM. $\boldsymbol{a}, \boldsymbol{b}$, Trial-by-trial analysis of escape times $(\boldsymbol{a})$ and path lengths $(\boldsymbol{b})$ taken to reach the hidden platform at a reversed position. Two-way ANOVA analysis of escape duration showed significant effect for genotype group $\left(F_{(1,396)}=45.68, p<0.0001\right)$, trial $\left(F_{(11,396)}=18.39\right.$, $p<0.0001)$ and trial-genotype interaction $\left(F_{(11,396)}=1.99, p=0.0284\right)$. Dunnett's multiple comparison test comparing to trial \#1 showed that the improvement in mGluR5 ${ }^{\text {IOxP/loxP }}$ mice reached significant difference at trial \#3 $\left({ }^{+++} p<0.001\right)$, The improvement in mGluR5 ${ }^{\text {del/del }}$ group became significant on fifth trial $\left({ }^{+} p<0.05\right)$. Two-way ANOVA analysis of path lengths also showed significant effect for genotype group $\left(F_{(1,396)}=35.52, p<0.0001\right)$, trial $\left(F_{(11,395)}=15.85, p<0.0001\right)$ and trialgenotype interaction $\left(F_{(11,396)}=1.95, p=0.0322\right)$. Dunnett's multiple comparison test showed that the improvement reached significant difference on trial \#3 ( $\left.{ }^{+++} p<0.001\right)$ for mGluR5 ${ }^{\text {del/del }}$ mice and fifth trial ( $\left.{ }^{+} p<0.05\right)$ for mGluR5 ${ }^{\text {loxP/loxP }}$ mice, respectively. Bonferroni posttests used to compare individual points between genotype groups detected significant differences in

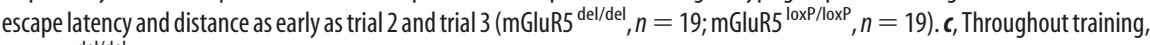
mGluR5 ${ }^{\text {del/del }}$ mice entered the NE quadrant (previous target location) more often then the control group $\left(F_{(1,180)}=11.70, p=\right.$ 0.0016 , for genotype, trial $0-5 ; F_{(5,180)}=3.88, p=0.0023$, for genotype-trial interaction, trial $\left.0-5\right)$ (left). Meanwhile, entries to SE quadrant (trial 0 -5, genotype effect: $F_{(1,180)}=2.90, p=0.097$, genotype-trial interaction: $F_{(5,180)}=0.45, p=0.8164$ ) and NW quadrant $\left(F_{(1,180)}=4.29, p=0.0455\right.$ for genotype; $F_{(5,180)}=1.44, p=0.2116$ for genotype-trial interaction) were much lower for the mGluR5 ${ }^{\text {del/del }}$ mice, and were more comparable to the control group. Trial 0 represents frequencies entered in each testing zone during probe test 1 from the same group of animals (mGluR5 ${ }^{\text {del/del }}, n=19 ;$ mGluR5 $^{\text {loxP/loxP }}, n=19$ ). Due to an unknown reason, mGluR5 ${ }^{\text {del/del }}$ mice performed poorly in trial 8 . They had much longer escape latency (Fig. $6 a$ ) and distance (Fig. $6 b$ ) than the control group. Their longer search in trial 8 also resulted in much higher number of entries into all quadrants compared with the control group. $\boldsymbol{d}$, Representative trajectories taken from trial 2, demonstrating that mGluR5 ${ }^{\text {del/del }}$ mice continued to return to the previous target location while control mice more rapidly found the new location. $\boldsymbol{e}, \boldsymbol{f}$, Second probe test performed $7 \mathrm{~d}$ after reversed platform training. Both groups remembered the last target location $(S W)\left(F_{(4,144)}=59.61, p<\right.$ 0.0001 for time spent in the different quadrants; $F_{(4,144)}=52.54, p<0.0001$ for number of entries). There was no significant genotype-quadrant interaction for time spent $\left(F_{(4,144)}=0.29, p=0.8815\right)(\boldsymbol{e})$ and entry numbers $\left(F_{(4,144)}=0.50, p=0.7369\right)$ $(\boldsymbol{f})$. Data are presented as SEM $\left({ }^{*} p<0.05,{ }^{* *} p<0.01,{ }^{* * *} p<0.001\right.$ for Bonferroni posttests; ${ }^{\# \#} p<0.01,{ }^{\# \# \#} p<0.001$ for two-way ANOVA; ${ }^{+} p<0.05,{ }^{++} p<0.001$ for Dunnett's multiple comparison test). 
training blocks. At the end of training, knock-out mice showed similar escape latencies as control group (Fig. 5). While it is unclear how these discrepancies might arise they may be due to differences in experimental protocols or strain differences in the mice used in each study.

The primary novel finding in our study is that mGluR5deficient mice are impaired in the extinction or reversal of learning. We used two inhibitory learning paradigms to assess a role for mGluR5 in these adaptive learning processes. In the first we found that mGluR5-deficient mice were completely unable to extinguish a previously acquired fear response (Figs. 3-4). In the second we found that mGluR5-deficient mice were impaired in their ability to relearn a reversed platform location after they had previously learned the task (Figs. 5-6).

The genetic components that contribute to fear extinction are not fully understood although a number of molecules have been implicated (Falls et al., 1992; Lin et al., 2001, 2003; Lu et al., 2001; Cain et al., 2002, 2004; Marsicano et al., 2002; Wang et al., 2004; Chen et al., 2005; Ponnusamy et al., 2005; Callaerts-Vegh et al., 2006; Chhatwal et al., 2006; Davis et al., 2006; Kamprath et al., 2006; Burgos-Robles et al., 2007; Kim et al., 2007; Sananbenesi et al., 2007; Sotres-Bayon et al., 2007; Fendt et al., 2008; Hefner et al., 2008) (for a review, see Myers and Davis, 2007). Among these are two members of metabotropic glutamate receptor family: mGluR1 (Kim et al., 2007) and mGluR7 (Callaerts-Vegh et al., 2006; Fendt et al., 2008). Thus, with the results of our study, it appears that mGluRs play a central role in fear extinction.

We also found a previously unknown role for mGluR5 in the reversal task of the water maze. Interestingly, we found that mGluR5 knock-out mice were more impaired in the reversal spatial learning task, than in the initial acquisition of spatial learning task of the regular water maze. Thus, mGluR5 knock-out mice provide yet another example that acquisition of standard spatial learning, and reversal spatial learning can be dissociated by genetic or pharmacological manipulation (Hawasli et al., 2007; Duffy et al., 2008).

The fundamental concept of inhibitory leaning, which is determined by the animal learning to suppress a prior learned response is broadly used to describe fear extinction studies (Bouton, 1993; Barad, 2005; Myers and Davis, 2007). The same concept of inhibitory learning has also been applied to reversal of spatial learning (Lattal and Abel, 2001; Varvel et al., 2005; Rossato et al., 2006; Duffy et al., 2008; Labrie et al., 2009). In the reversal task, mice learn that navigating to an area where they had previously learned a platform location is no longer an effective escape strategy. Consequently, mice able to perform this task return to this region with decreasing frequency during the training. Thus although fear extinction and reversal spatial learning are quite separate and distinct tasks they are linked as inhibitory learning tasks which require an active suppression of previously learned associations (Lattal and Abel, 2001; Barad, 2005; Myers and Davis, 2007). Our finding that mice lacking mGluR5 are impaired in both the fear extinction and reversal spatial learning, suggest that these two inhibitory learning paradigms may share common mechanistic properties which involve signaling through mGluR5. There are not many other examples of signaling molecules that have been demonstrated to have similar clear roles in multiple forms of inhibitory learning. However, one such molecule is the CB1 receptor (Marsicano et al., 2002; Varvel et al., 2005). CB1 knock-out mice have significant deficits in fear extinction (Marsicano et al., 2002) and in the reversed MWM task (Varvel et al., 2005) similar to the mGluR5-deficient mice. Interestingly, mGluR5 and CB1 receptors are linked together by their roles in synaptic plasticity. mGluR5 activation is required for endocannabinoid-mediated longterm depression of GABAergic synapses (eCB-LTD) in the hip- pocampus (Chevaleyre and Castillo, 2003) and depolarizationinduced suppression of inhibition (DSI) in the basolateral amygdala (Zhu and Lovinger, 2005). In particular, the mechanisms of DSI in the basolateral amygdala require mGluR5-mediated release of endocannabinoids and activation of presynaptic CB1 receptors. Therefore it is interesting to speculate that a potential cellular basis for inhibitory learning might be the depression of inhibitory synapses in these brain regions. The findings of our study demonstrate a clear role for mGluR5 in fear extinction and reversal of a spatial task, suggesting that both forms of learning could be linked. However a definitive shared molecular link between these two forms of inhibitory learning will require further experimental clarification.

Neural circuits in several different brain regions play a role in fear extinction and reversal tasks. These include the basolateral nucleus of the amygdala (Falls et al., 1992; Walker et al., 2002), the prefrontal cortex (Quirk et al., 2000; Milad and Quirk, 2002; Burgos-Robles et al., 2007) and the hippocampus (Sananbenesi et al., 2007). mGluR5 is expressed in all these structures, and therefore whether or not mGluR5 signaling in all of these regions, or in specific locales are required for inhibitory learning, remains an open question. In future studies, the novel mice described here will enable us to ablate mGluR5 in specific brain regions to directly address this question, and will provide more detailed information of which circuits are involved in inhibitory learning. Reversal or extinction of previously acquired memories allows animals to adapt to a novel environment or situation. These mechanisms are perturbed in several neuropsychiatric disorders in which traumatic memories persist. Therefore mGluR5 provides a potential target for therapeutic intervention in processes of maladaptive learning.

\section{References}

Abe T, Sugihara H, Nawa H, Shigemoto R, Mizuno N, Nakanishi S (1992) Molecular characterization of a novel metabotropic glutamate receptor mGluR5 coupled to inositol phosphate/Ca2 + signal transduction. J Biol Chem 267:13361-13368.

Balschun D, Wetzel W (2002) Inhibition of mGluR5 blocks hippocampal LTP in vivo and spatial learning in rats. Pharmacol Biochem Behav 73:375-380.

Barad M (2005) Fear extinction in rodents: basic insight to clinical promise. Curr Opin Neurobiol 15:710-715.

Bikbaev A, Neyman S, Ngomba RT, Conn J, Nicoletti F, Manahan-Vaughan D (2008) MGluR5 mediates the interaction between late-LTP, network activity, and learning. PLoS ONE 3:e2155.

Bouton ME (1993) Context, time, and memory retrieval in the interference paradigms of Pavlovian learning. Psychol Bull 114:80-99.

Bouton ME, Bolles RC (1979) Role of conditioned contextual stimuli in reinstatement of extinguished fear. J Exp Psychol Anim Behav Process 5:368-378.

Brody SA, Dulawa SC, Conquet F, Geyer MA (2004) Assessment of a prepulse inhibition deficit in a mutant mouse lacking mGlu5 receptors. Mol Psychiatry 9:35-41.

Burgos-Robles A, Vidal-Gonzalez I, Santini E, Quirk GJ (2007) Consolidation of fear extinction requires NMDA receptor-dependent bursting in the ventromedial prefrontal cortex. Neuron 53:871-880.

Cain CK, Blouin AM, Barad M (2002) L-type voltage-gated calcium channels are required for extinction, but not for acquisition or expression, of conditional fear in mice. J Neurosci 22:9113-9121.

Cain CK, Blouin AM, Barad M (2004) Adrenergic transmission facilitates extinction of conditional fear in mice. Learn Mem 11:179-187.

Callaerts-Vegh Z, Beckers T, Ball SM, Baeyens F, Callaerts PF, Cryan JF, Molnar E, D’Hooge R (2006) Concomitant deficits in working memory and fear extinction are functionally dissociated from reduced anxiety in metabotropic glutamate receptor 7-deficient mice. J Neurosci 26:6573-6582.

Chen X, Garelick MG, Wang H, Lil V, Athos J, Storm DR (2005) PI3 kinase signaling is required for retrieval and extinction of contextual memory. Nat Neurosci 8:925-931. 
Chevaleyre V, Castillo PE (2003) Heterosynaptic LTD of hippocampal GABAergic synapses: a novel role of endocannabinoids in regulating excitability. Neuron 38:461-472.

Chhatwal JP, Stanek-Rattiner L, Davis M, Ressler KJ (2006) Amygdala BDNF signaling is required for consolidation but not encoding of extinction. Nat Neurosci 9:870-872.

Chiamulera C, Epping-Jordan MP, Zocchi A, Marcon C, Cottiny C, Tacconi S, Corsi M, Orzi F, Conquet F (2001) Reinforcing and locomotor stimulant effects of cocaine are absent in mGluR5 null mutant mice. Nat Neurosci 4:873-874.

Davis M, Ressler K, Rothbaum BO, Richardson R (2006) Effects of D-cycloserine on extinction: translation from preclinical to clinical work. Biol Psychiatry 60:369-375.

Dölen G, Osterweil E, Rao BS, Smith GB, Auerbach BD, Chattarji S, Bear MF (2007) Correction of fragile X syndrome in mice. Neuron 56:955-962.

Duffy S, Labrie V, Roder JC (2008) D-serine augments NMDA-NR2B receptor-dependent hippocampal long-term depression and spatial reversal learning. Neuropsychopharmacology 33:1004-1018.

Falls WA, Miserendino MJ, Davis M (1992) Extinction of fear-potentiated startle: blockade by infusion of an NMDA antagonist into the amygdala. J Neurosci 12:854-863.

Fendt M, Schmid S, Thakker DR, Jacobson LH, Yamamoto R, Mitsukawa K, Maier R, Natt F, Hüsken D, Kelly PH, McAllister KH, Hoyer D, van der Putten H, Cryan JF, Flor PJ (2008) mGluR7 facilitates extinction of aversive memories and controls amygdala plasticity. Mol Psychiatry 13:970-979.

Hawasli AH, Benavides DR, Nguyen C, Kansy JW, Hayashi K, Chambon P, Greengard P, Powell CM, Cooper DC, Bibb JA (2007) Cyclindependent kinase 5 governs learning and synaptic plasticity via control of NMDAR degradation. Nat Neurosci 10:880-886.

Hefner K, Whittle N, Juhasz J, Norcross M, Karlsson RM, Saksida LM, Bussey TJ, Singewald N, Holmes A (2008) Impaired fear extinction learning and cortico-amygdala circuit abnormalities in a common genetic mouse strain. J Neurosci 28:8074-8085.

Huber KM, Kayser MS, Bear MF (2000) Role for rapid dendritic protein synthesis in hippocampal mGluR-dependent long-term depression. Science 288:1254-1257.

Jia Z, Lu Y, Henderson J, Taverna F, Romano C, Abramow-Newerly W, Wojtowicz JM, Roder J (1998) Selective abolition of the NMDA component of long-term potentiation in mice lacking mGluR5. Learn Mem 5:331-343.

Kamprath K, Marsicano G, Tang J, Monory K, Bisogno T, Di Marzo V, Lutz B, Wotjak CT (2006) Cannabinoid CB1 receptor mediates fear extinction via habituation-like processes. J Neurosci 26:6677-6686.

Kim J, Lee S, Park H, Song B, Hong I, Geum D, Shin K, Choi S (2007) Blockade of amygdala metabotropic glutamate receptor subtype 1 impairs fear extinction. Biochem Biophys Res Commun 355:188-193.

Labrie V, Duffy S, Wang W, Barger SW, Baker GB, Roder JC (2009) Genetic inactivation of D-amino acid oxidase enhances extinction and reversal learning in mice. Learn Mem 16:28-37.

Lattal KM, Abel T (2001) Different requirements for protein synthesis in acquisition and extinction of spatial preferences and context-evoked fear. J Neurosci 21:5773-5780.

LeDoux JE (2000) Emotion circuits in the brain. Annu Rev Neurosci 23:155-184.

Lin CH, Yeh SH, Lin CH, Lu KT, Leu TH, Chang WC, Gean PW (2001) A role for the PI-3 kinase signaling pathway in fear conditioning and synaptic plasticity in the amygdala. Neuron 31:841-851.

Lin CH, Yeh SH, Leu TH, Chang WC, Wang ST, Gean PW (2003) Identification of calcineurin as a key signal in the extinction of fear memory. J Neurosci 23:1574-1579.

Lu KT, Walker DL, Davis M (2001) Mitogen-activated protein kinase cascade in the basolateral nucleus of amygdala is involved in extinction of fear-potentiated startle. J Neurosci 21:RC162.

Lu YM, Jia Z, Janus C, Henderson JT, Gerlai R, Wojtowicz JM, Roder JC (1997) Mice lacking metabotropic glutamate receptor 5 show impaired learning and reduced CA1 long-term potentiation (LTP) but normal CA3 LTP. J Neurosci 17:5196-5205.

Marino MJ, Conn PJ (2006) Glutamate-based therapeutic approaches: allo- steric modulators of metabotropic glutamate receptors. Curr Opin Pharmacol 6:98-102.

Marsicano G, Wotjak CT, Azad SC, Bisogno T, Rammes G, Cascio MG, Hermann H, Tang J, Hofmann C, Zieglgänsberger W, Di Marzo V, Lutz B (2002) The endogenous cannabinoid system controls extinction of aversive memories. Nature 418:530-534.

Milad MR, Quirk GJ (2002) Neurons in medial prefrontal cortex signal memory for fear extinction. Nature 420:70-74.

Myers KM, Davis M (2007) Mechanisms of fear extinction. Mol Psychiatry 12:120-150.

Myers KM, Ressler KJ, Davis M (2006) Different mechanisms of fear extinction dependent on length of time since fear acquisition. Learn Mem 13:216-223.

Nagy A, Rossant J, Nagy R, Abramow-Newerly W, Roder JC (1993) Derivation of completely cell culture-derived mice from early-passage embryonic stem cells. Proc Natl Acad Sci U S A 90:8424-8428.

Nakanishi S (1992) Molecular diversity of glutamate receptors and implications for brain function. Science 258:597-603.

O'Gorman S, Dagenais NA, Qian M, Marchuk Y (1997) Protamine-Cre recombinase transgenes efficiently recombine target sequences in the male germ line of mice, but not in embryonic stem cells. Proc Natl Acad Sci U S A 94:14602-14607.

Ponnusamy R, Nissim HA, Barad M (2005) Systemic blockade of D2-like dopamine receptors facilitates extinction of conditioned fear in mice. Learn Mem 12:399-406.

Quirk GJ, Russo GK, Barron JL, Lebron K (2000) The role of ventromedial prefrontal cortex in the recovery of extinguished fear. J Neurosci 20:6225-6231.

Rodrigues SM, Bauer EP, Farb CR, Schafe GE, LeDoux JE (2002) The group I metabotropic glutamate receptor mGluR5 is required for fear memory formation and long-term potentiation in the lateral amygdala. J Neurosci 22:5219-5229.

Rossato JI, Bevilaqua LR, Medina JH, Izquierdo I, Cammarota M (2006) Retrieval induces hippocampal-dependent reconsolidation of spatial memory. Learn Mem 13:431-440.

Sananbenesi F, Fischer A, Wang X, Schrick C, Neve R, Radulovic J, Tsai LH (2007) A hippocampal Cdk5 pathway regulates extinction of contextual fear. Nat Neurosci 10:1012-1019.

Schulz B, Fendt M, Gasparini F, Lingenhöhl K, Kuhn R, Koch M (2001) The metabotropic glutamate receptor antagonist 2-methyl-6(phenylethynyl)-pyridine (MPEP) blocks fear conditioning in rats. Neuropharmacology 41:1-7.

Slassi A, Isaac M, Edwards L, Minidis A, Wensbo D, Mattsson J, Nilsson K, Raboisson P, McLeod D, Stormann TM, Hammerland LG, Johnson E (2005) Recent advances in non-competitive mGlu5 receptor antagonists and their potential therapeutic applications. Curr Top Med Chem 5:897-911.

Sotres-Bayon F, Bush DE, LeDoux JE (2007) Acquisition of fear extinction requires activation of NR2B-containing NMDA receptors in the lateral amygdala. Neuropsychopharmacology 32:1929-1940.

van Praag H, Shubert T, Zhao C, Gage FH (2005) Exercise enhances learning and hippocampal neurogenesis in aged mice. J Neurosci 25:8680-8685.

Varvel SA, Anum EA, Lichtman AH (2005) Disruption of CB(1) receptor signaling impairs extinction of spatial memory in mice. Psychopharmacology 179:863-872.

Walker DL, Ressler KJ, Lu KT, Davis M (2002) Facilitation of conditioned fear extinction by systemic administration or intra-amygdala infusions of D-cycloserine as assessed with fear-potentiated startle in rats. J Neurosci 22:2343-2351.

Wang H, Ferguson GD, Pineda VV, Cundiff PE, Storm DR (2004) Overexpression of type- 1 adenylyl cyclase in mouse forebrain enhances recognition memory and LTP. Nat Neurosci 7:635-642.

Zhang CL, Zou Y, He W, Gage FH, Evans RM (2008) A role for adult TLXpositive neural stem cells in learning and behaviour. Nature 451:1004-1007.

Zhu PJ, Lovinger DM (2005) Retrograde endocannabinoid signaling in a postsynaptic neuron/synaptic bouton preparation from basolateral amygdala. J Neurosci 25:6199-6207. 